\title{
Physics education students' science process skills
}

\author{
Darmaji Darmaji, Dwi Agus Kurniawan, Irdianti Irdianti \\ Department of Mathematics and Natural Sciences Education, Universitas Jambi, Indonesia
}

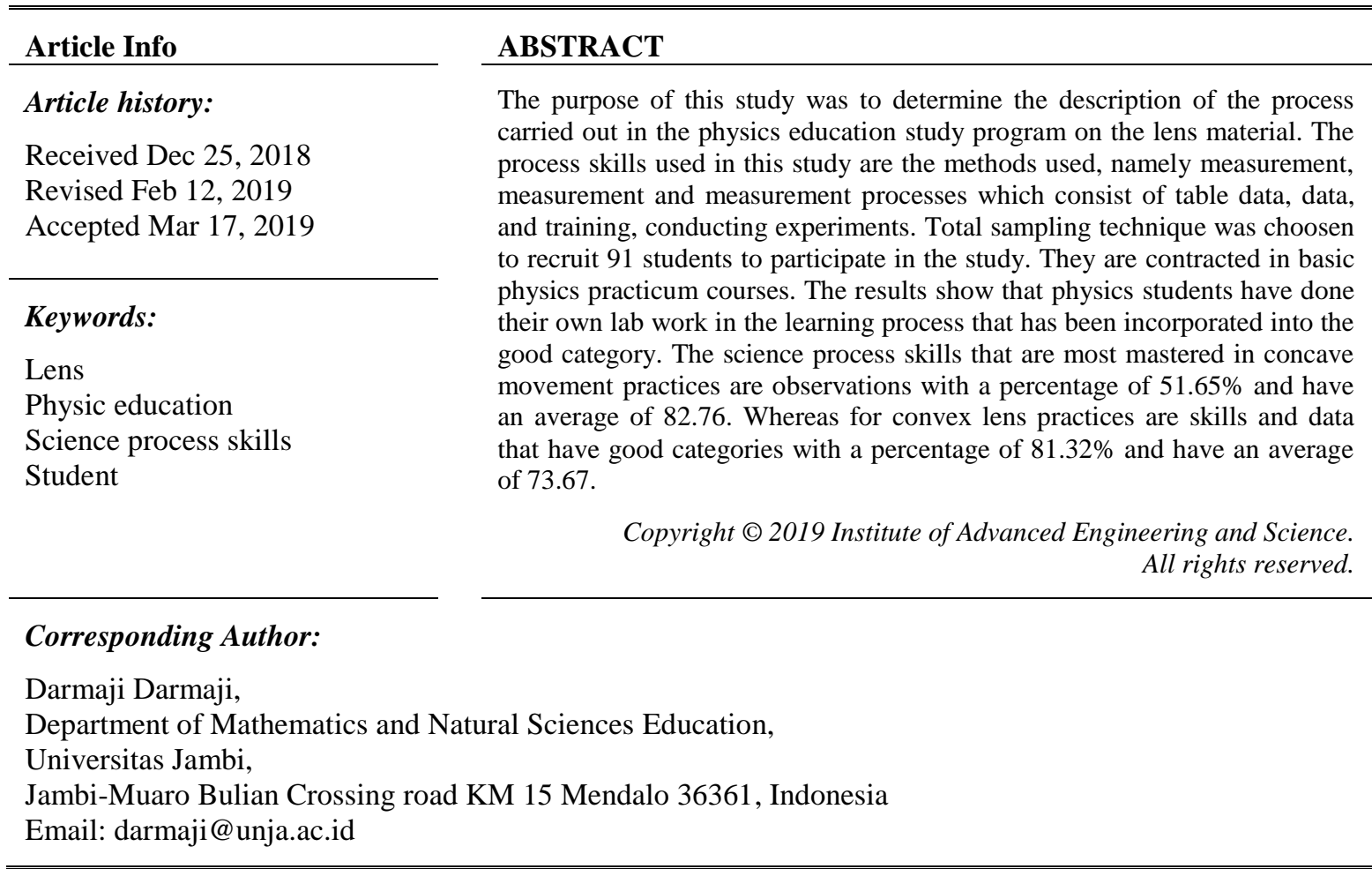

\section{INTRODUCTION}

In this globalization era, quality human resources will become the foundation of a nation incompetency. Thus, it has become a top priority for education to produce generations of intellectuals, one of which is through higher education. Colleges consist of various faculties, one of which is the faculty of teacher training and education. The physics education study program is a study program in the faculty of education and education which has the aim of producing graduates who are skilled in various aspects of competency such as knowledge, attitudes and skills.

Skill competency is a competency that must be possessed by physics education students. This is based on physics which is one branch of natural science that requires an investigation or scientific work to get a concept, principle, theory, and law. One of the processes of scientific inquiry can be carried out by practical activities. One way for someone to acquire and develop a set of knowledge he or she have is through practical activities [1]. Nwagbo and Chukelu [2] stated that practical activity was more effective in fostering students the acquisition of science process skills. Shahali and Halim [3] also said that physics education aims to develop student skills in investigations supported by scientific knowledge. The skills needed to develop scientific work are science process skills [4].

Science process skills are considered to give students meaningful learning experiences because they help students to achieve high-level thinking [5]. Kazeni [6] revealed that mastering science process skills allows students to acquire the skills needed to solve everyday problems. Science process skills are thinking skills used to process information, solve problems and form conclusions [7]. Semiawan [8] wrote that the development of process skills in students will help students find and develop their own facts and concepts and the attitudes and values demanded. Whereas Rauf [9] said that science process skills are needed to show how to obtain scientific concepts. In learning science, process skills consist of basic process skills and integrated process skills [10]. 
The skills of the basic process include observing, classifying, communicating, measuring, concluding, predicting Chabalengula, et al [11]. While integrated skills are more complex skills that include identifying variables, constructing a table of data, constructing a graph, describing relationships between variables, acquiring and processing data, analyzing investigations, constructing hypotheses, defining operational variables, designing investigation and experimenting [12]

Turiman [10] basic process skills are skills that must be mastered before mastering integrated process skills. Students who do not have basic science skills such as observation skills will make the student unable to obtain information and find the problem to be solved. Whereas observation ability according to Rezba [12] can develop other skills such as concluding skills, communication, predictive measures, drawing conclusions. So it can be said that if students do not master basic process skills and are integrated together then it will be difficult for students to develop higher abilities and this will affect students later when they become a teacher.

The teacher is a professional educator who has the task of guiding, training and building the knowledge of students [13]. Therefore, in building the knowledge of their students, a teacher and prospective physics teacher must have process skills in teaching physics [14]. Chabalengula, et al [11] In order to be able to teach effectively, a teacher should have a good understanding of concepts and strong process skills. Miles [15]. A teacher and knowledge and materials needed to teach the science process skills. In addition, the scientific process has competencies that can be used as a means to gain knowledge and understand how knowledge is obtained. [16]. A physics teacher or physics teacher candidate who does not have process skills, then when learning takes place the teacher can only explain the theory with conventional methods. According to Murni [17], the teaching process of physics conducted conventionally makes students treat physics as a collection of knowledge and tend to only master the concepts of physics without understanding the process of the occurrence of these concepts. In addition, learning that takes place will be boring for students, because of their inability to imagine an event in science with concrete and correct.

Based on the description above, it can be concluded that the development of science process skills at the level of education must continue to be carried out because in reality the field is still found by students and teachers who do not master science process skills. Therefore, research needs to be done to describe the basic process skills of students through basic physics practice 2 on concave lens material and convex lenses, where later the results of this study can be used as preliminary data for research on subsequent science process skills at Universitas Jambi.

\section{RESEARCH METHOD}

This study uses a quantitative approach with the Pre-Experimental Design One-Shot Case Study research method. This research was carried out in the laboratory of Physics Education and Teaching and Education Faculty of Universitas Jambi in the even semester of the 2018 academic year. The samples taken in this study were all physical education students who contracted basic physics two subjects as many as 91 people. The sampling technique used in this study was using total sampling techniques. The total sampling technique is a sampling technique if all members of the population are used as samples [18]. A sample of 91 students were formed into groups with each group consisting of four to five students. Each student was given a treatment in the form of a practical science-based skill process guide with concave lens material and a convex lens. Furthermore, students in each group conduct practicum using tools and materials provided by the researcher.

The instrument used in this study is the observation sheet of science process skills. The observation sheet is used to obtain a description of student science process skills. Observations carried out in this study were assisted by observers totaling 20 people. The data on the observation sheet will be analyzed using descriptive statistics and the percentage for each indicator is searched then expressed in several categories, namely the category Very Not Good with a range of $25-43.75 \%$, category Not Good with a range of $43.76-$ $62.5 \%$, category Good with a range of $62.51-81.25 \%$, and the category Very Good with a range of $81.26-$ $100 \%$. The percentages for each category of science process skills mastery can be seen in Table 1 . The science process skills focused in this research are basic process skills which include observation, classification, measuring and integration process skills which include skills in arranging data tables, obtaining and processing data, conduct an experiment with a total of 24 statement items. 
Table 1. Category of mastery of the reliability of the student science process

\begin{tabular}{ccc}
\hline No & Interval $(\%)$ & Category \\
\hline 1 & $25.00-43.75$ & Very not good \\
2 & $43.76-62.500$ & Not good \\
3 & $62.51-81.25$ & Good \\
4 & $81.26-100.00$ & Very good \\
\hline
\end{tabular}

\section{RESULTS AND DISCUSSION}

Bundu [19] wrote that the importance of mastering science process skills by students can facilitate students in understanding abstract concepts if learning through concrete objects and carried out by students themselves through direct learning experiences. Science process skills are skills that facilitate learning in physics, ensure students active participation, develop a sense of student responsibility in their own learning, increase permanent learning, and also make students obtain research methods and methods, namely ensuring thinking and behaving like a scientist.

The science process skills focused on this research are basic process skills including observation, calcification and measuring skills and integrated process skills including compiling data tables, obtaining and processing data and conducting experiments. The results of observation of science process skills of students of Universitas Jambi physics education in concave lens practicum activities are presented in Table 2.

Table 2. Results of descriptive analysis of basic science process skills and integration of concave

\begin{tabular}{|c|c|c|c|c|c|c|c|}
\hline & Indicator & Min & Mov & Panos & Moon & $\mathrm{Std}$ & Som \\
\hline \multirow{3}{*}{ Basic } & Observing & 37.50 & 100.00 & 62.50 & 82.76 & 14.32 & 1.50 \\
\hline & Classifying & 25.00 & 100.00 & 75.00 & 84.34 & 18.12 & 1.90 \\
\hline & Measuring & 37.50 & 100.00 & 62.50 & 75.76 & 18.16 & 1.90 \\
\hline \multirow{3}{*}{ Integrated } & Constructing a table of data & 50.00 & 100.00 & 50.00 & 82.19 & 16.09 & 1.69 \\
\hline & Acquiring and processing data & 41.67 & 100.00 & 58.33 & 71.98 & 13.18 & 1.38 \\
\hline & Experimenting & 32.14 & 100.00 & 67.86 & 80.97 & 15.24 & 1.60 \\
\hline
\end{tabular}

Table 2 shows the average mastery of process skills 91 students are at a relatively good level, where for basic process skills which include observation skills have a mean of 82.76, classification skills have a mean of 84.34, and measuring skills have a mean of 75.76. Whereas for integrated process skills which include skills in arranging data tables having a mean of 82.19 , the skills of obtaining and processing data have a mean of 71.98 and for skills to conduct experiments have a mean of 80.97 . For the percentage data and the mastery category of science process skills students in concave lens practicum can be seen in Table 3 .

Table 3. Percentage and category of mastery of science process skills of students in concave lens practicum.

\begin{tabular}{|c|c|c|c|}
\hline Science process skills & Indicator & Category & $\%$ \\
\hline \multirow{12}{*}{ Basic } & \multirow{4}{*}{ Observing } & Very not good & 2.20 \\
\hline & & Not good & 14.29 \\
\hline & & Good & 31.87 \\
\hline & & Very good & 51.65 \\
\hline & \multirow{5}{*}{ Classifying } & Very not good & 1.10 \\
\hline & & Not good & 10.99 \\
\hline & & Good & 37.36 \\
\hline & & Very good & 50.55 \\
\hline & & Very not good & 7.69 \\
\hline & \multirow{3}{*}{ Measuring } & Not good & 17.58 \\
\hline & & Good & 40.66 \\
\hline & & Very good & 34.07 \\
\hline \multirow{12}{*}{ Integrated } & \multirow{4}{*}{$\begin{array}{l}\text { Constructing a } \\
\text { table of data }\end{array}$} & Very not good & 0.00 \\
\hline & & Not good & 13.19 \\
\hline & & Good & 32.97 \\
\hline & & Very good & 53.85 \\
\hline & \multirow{4}{*}{$\begin{array}{l}\text { Acquiring and } \\
\text { processing data }\end{array}$} & Very not good & 1.10 \\
\hline & & Not good & 24.18 \\
\hline & & Good & 58.24 \\
\hline & & Very good & 16.48 \\
\hline & \multirow{4}{*}{ Experimenting } & Very not good & 3.30 \\
\hline & & Not good & 9.89 \\
\hline & & Good & 29.67 \\
\hline & & Very good & 57.14 \\
\hline
\end{tabular}


Table 3 shows the percentage of observations for science process skills from 91 students in concave lens practices. Obtained for student observation skills have a high percentage in the excellent category with a percentage of $51.65 \%$, classification skills have a high percentage in the excellent category with a percentage of $50.55 \%$, measuring skills have a high percentage in good categories with large the percentage of $40.66 \%$, the skill in compiling data tables has a high percentage in the excellent category with a percentage of $53.85 \%$, the skill of obtaining and processing data has a high percentage in the good category with a percentage of $58.24 \%$, the skill in conducting experiments has the high percentage in the category is very good with a percentage of $57.14 \%$.

The science process skills in the concave lens practicum most mastered by students are observation skills with a percentage of $51.65 \%$ and have a mean of 82.76 . This shows that students are skilled in observing to determine the tools and materials used, observe the nature of the shadow, observe the scale in measurement and skilled in observing the data obtained. This is because every form of learning in both the classroom and laboratory begins with an observation [20]. Feynman [21] says that mastering observation skills has a good impact on students, where students can relate the direct experience to the theories they know. In addition, observation ability is the most basic skill that supports the mastery of the next skill [22]. When students make observations and analyze the results of observations, students will find patterns that can predict conditions that have not occurred or are observed. So it is not surprising that in this study other process skills were found to be the main focus of the research having a high percentage and average in the good and skilled categories.

While the observation results of science process skills of Universitas Jambi physics education students in convex lens practicum activities are presented in Table 4.

Table 4. Results of descriptive analysis of basic science process skills and integration of convex lens practicum

\begin{tabular}{cccccccc}
\hline Science process skills & Indicator & Min & Max & Range & Mean & Std & Sem \\
\hline \multirow{5}{*}{ Basic } & Observing & 50.00 & 100.00 & 50.00 & 84.75 & 12.88 & 1.35 \\
& $\begin{array}{c}\text { Classifying } \\
\text { Measuring }\end{array}$ & 50.00 & 100.00 & 50.00 & 79.95 & 16.76 & 1.76 \\
Integrated & $\begin{array}{c}\text { Constructing a } \\
\text { table of data }\end{array}$ & 25.00 & 100.00 & 75.00 & 75.16 & 15.33 & 1.61 \\
& $\begin{array}{c}\text { Acquiring and } \\
\text { processing } \\
\text { data }\end{array}$ & 25.00 & 100.00 & 75.00 & 82.60 & 11.16 & 1.17 \\
& Experimenting & 47.73 & 100.00 & 52.27 & 84.35 & 12.31 & 1.29 \\
\hline
\end{tabular}

Table 4 shows the average mastery of process skills 91 students are at a relatively good level, where for basic process skills which include observation skills have a mean of 84.75 , classification skills have a mean of 79.95, and measuring skills have a mean of 75.16. Whereas for integrated process skills which include skills in compiling data tables have a mean of 82.60 , skills in obtaining and processing data have a mean of 73.67 and for skills to conduct experiments have a mean of 84.35. For the percentage data and the mastery category of science process skills students in convex lens practicums can be seen in Table 5 .

Table 5 shows the percentage of observations for science process skills from 91 students in concave lens practices. Science process skills that have a high percentage in the good category are classification skills and skills in obtaining and processing data with a percentage of $51.65 \%$ and $81.32 \%$ respectively. While the science process skills that have the highest percentage in the good category are observation skills with a percentage of $51.65 \%$, skills measuring with a percentage of $40.66 \%$, skills in compiling data tables with a percentage of $68.13 \%$ and skills in conducting experiments with a percentage of 52.75 .

In convex lens practices, the science process skills most mastered by students are the skills of acquiring and processing data. The skills to obtain and process data are part of integrated process skills which have a high percentage in the good category with a percentage of $81.32 \%$ and have a mean of 73.67 . This is influenced by classification skills. If a skilled student classifies tools and materials when the practice takes place, students can obtain and process data. This is in accordance with the opinion of Rezba, et al [12] who said that classification process skills are process skills that are important in obtaining and processing data used to obtain concepts. In addition, according to Zeiden and Jayosi [23] said that basic process skills are skills that support the development of integrated process skills. This means that basic process skills will support the development of integrated process skills, where classification skills are one part of basic process skills. 
Table 5. Percentage and category of mastery of student science process skills in convex lens practicum.

\begin{tabular}{|c|c|c|c|}
\hline Science process skills & Indicator & Category & $\%$ \\
\hline \multirow{12}{*}{ Basic } & \multirow{5}{*}{ Observing } & Very not good & 0.00 \\
\hline & & Not good & 6.59 \\
\hline & & Good & $4 ., 76$ \\
\hline & & Very good & 51.65 \\
\hline & & Very not good & 0.00 \\
\hline & \multirow{4}{*}{ Classifying } & Not good & 14.29 \\
\hline & & Good & 51.65 \\
\hline & & Very good & 34.07 \\
\hline & & Very not good & 2.20 \\
\hline & \multirow{4}{*}{ Measuring } & Not good & 19.78 \\
\hline & & Good & 37.36 \\
\hline & & Very good & 40.66 \\
\hline \multirow{12}{*}{ Integrated } & & Very not good & 1.10 \\
\hline & \multirow{3}{*}{$\begin{array}{l}\text { Constructing a } \\
\text { table of data }\end{array}$} & Not good & 2.20 \\
\hline & & Good & 28.57 \\
\hline & & Very good & 68.13 \\
\hline & \multirow{4}{*}{$\begin{array}{c}\text { Acquiring and } \\
\text { processing } \\
\text { data }\end{array}$} & Very not good & 2.20 \\
\hline & & Not good & 5.49 \\
\hline & & Good & 81.32 \\
\hline & & Very good & 10.99 \\
\hline & \multirow{4}{*}{ Experimenting } & Very not good & 0.00 \\
\hline & & Not good & 4.40 \\
\hline & & Good & 42.86 \\
\hline & & Very good & 52.75 \\
\hline
\end{tabular}

\section{CONCLUSION}

From the results and analysis of the observation sheet data, it can be concluded that the most dominant indicator of science process skills in Jambi university physics education students in concave lens practicum is the most prominent is the observation skill indicator with a mastery percentage of $51.65 \%$. Whereas the most dominant indicator of science process skills in Jambi University physics education students in concave lens practicum is an indicator of skill in acquiring and processing skilled data with a percentage of mastery of $81.32 \%$. The results of this study are preliminary descriptions of science process skills with advantages in order to improve the science process skills of students through practical activities. While the weaknesses in this study are the difficulties of students in adapting by using practical guides that require students to complete laboratory activities independently. Physics education study programs should be able to apply process skill-based practice manuals to improve science process skills through practical activities.

\section{REFERENCES}

[1] Misbah, et al., "Development of 5M-based basic physics practicum instructions for training science process skills and wasaka characters," FLUX Physics Journal, vol. 15 (1), pp. 26-30, 2018.

[2] Nwagbo, C., \& Chukelu, U. C., "Effects of biology practical activities on students' process skill acquisition," Journal of the Science Association of Nigeria (JSTAN), vol. 46 (1), pp. 58-70, 2011.

[3] Shahali, et al., "Primary school teachers' understanding of science process skills in relation to their teaching qualifications and teaching experience," Research in Science Education, vol. 47(2), pp. 257-281, 2017.

[4] Rustaman, N.Y., "Basic ability to work scientifically in science", Paper at Biology Education Seminar - FKIP UNPAS Bandung, 2003.

[5] Tilakaratnea, C. T. K. \& Ekanayakeb, T. M. S. S. K. Y., "Achievement level of science process skills of junior secondary students: based on a sample of grade six and seven students from Sri Lanka," International Journal of Environmental \& Science Education, vol. 12(9), pp. 2089-2108, 2017.

[6] Kazeni, M. M. M., "Development and validation of a test integrated science process skills for the further education and training learners," (Unpublished Master Thesis), University of Pretoria South Africa, 2005.

[7] Özgelen, S., "Students' science process skills within a cognitive domain framework," Eurasia Journal of Mathematics, Science \& Technology Education, vol. 8(4), pp. 283-292, 2012.

[8] Semiawan, C., "Process Skills Approach", Jakarta: PT Gramedia, 1992.

[9] Rauf A A R., "Inculcation of science process skills in a science classroom," Can. Cent. Sci. Educ. Asian Soc. Sc, vol. 9, pp. 1911-2025, 2013.

[10] Turiman, P., et al., "Fostering the 21st century skills through scientific literacy and science process skills," Procedia-Social and Behavioral Sciences, vol 59, pp. 110-116, 2012.

[11] Chabalengula, V. M., et al., "How pre-service teachers' understand and perform science process skills," Eurasia Journal of Mathematics, Science \& Technology Education, vol. 8(3), pp. 167-176, 2012. 
[12] Rezba, R.J., et al., "Science process skills," Learning and Assessing. Iowa: Kendall/Hunt Publishing Co, 1995.

[13] Republic of Indonesia Law Number 14 of 2005 concerning Teachers and Lecturers.

[14] Settlage, J., \& Southerland, S.A. "Teaching science to every child,"New York: Routledge Taylor \& Francis Group, 2007.

[15] Miles E., "In-service elementary teachers' familiarity, interest, conceptual knowledge, and performance on science process skills," (Unpublished Master Thesis). Southern Illinois University Carbondale, USA. Available from ProQuest, UMI Dissertations Publishing, (UMI No. 1482656), 2010.

[16] Bati, K., "The awareness levels of pre-school education teachers regarding science process skills," Procedia-Social and Behavioral Sciences, vol. 2(2), pp. 1993-1999, 2010.

[17] Murni, M., "Profile of student's science process skills and learning design to practice it", Periodic Scientific Physical Education, vol. 6 (1), pp. 118-129, 2018.

[18] Sugiyono. "Methods of quantitative, qualitative and R \& D research", Bandung: ALFABETA, 2016.

[19] Bundu, P., "Process skills assessment and scientific attitudes in science-elementary learning," Jakarta: Ministry of National Education, 2006.

[20] Ango, M. L., "Mastery of science process skills and their effective use in the teaching of science," Educology of Science Education in the Nigerian Context. Online Submission, vol. 16(1), pp. 11-30, 2002.

[21] Feynman, R., "Goals of the introductory physics laboratory," American Journal of Physics, vol. 66(6), pp. 483-485, 1998.

[22] Bass, J. E., "Methods for teaching science as inquiry," Person Merril, 2008.

[23] Zeidan, A. H., \& Jayosi, M. R., "Science process skills and attitudes toward science among palestinian secondary school students," World journal of Education, vol. 5(1), pp. 13, 2014. 